
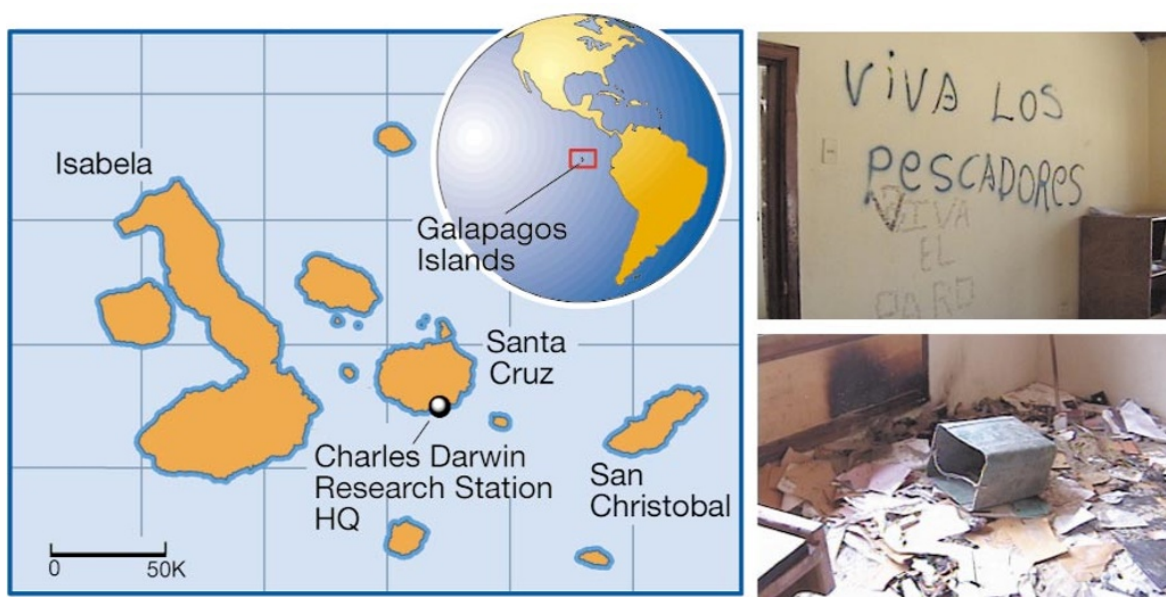

Fishermen on the Galapagos threatened visitors, and ransacked one scientist's home.

\title{
Galapagos ecologists under threat from violent protests
}

\section{Mark Schrope}

Forced to flee by angry fishermen protesting against lobster quotas, staff at the Charles Darwin Research Station in the Galapagos Islands spent a night late last month cowering in a mangrove thicket, until they were rescued by the Ecuadorian navy.

Work at the famous ecological research station is returning to normal, but eminent researchers associated with it are calling on Ecuador, which governs the Galapagos, to provide better protection for researchers and to stand by the measures needed to conserve the islands' ecosystems.

Researchers say that during unrest in November, the fishermen made death threats, ransacked one scientist's home, threatened tourists, and forced research and nationalpark facilities on three islands to close.

The United Nations has made the islands, which lie 1,000 kilometres west of Ecuador, a World Heritage Site. In the 165 years since Charles Darwin's famous visit there aboard the Beagle, they have been seen as an exceptional natural evolutionary laboratory, on account of their isolation.

But efforts to conserve their ecosystems have long been at odds with local interests, including those of fishermen. The recent unrest was the latest in a string of similar incidents.

The research station's main facilities are on Santa Cruz Island, and it is operated by the international Darwin Foundation under a charter from the United Nations Educational, Scientific and Cultural Organization. Because it works with park officials to implement and oversee conservation on the Galapagos, the research station has become a focal point of the sometimes violent protests.

But researchers say that the latest incident included bolder and broader attacks on individual visitors. "What's new about this is that it's targets other than institutions. In that sense it's an escalation," says David Anderson, a biologist at Wake Forest University in North Carolina, who recently returned there from the Galapagos.

Anderson and colleagues at Princeton, and Yale universities and the German Max Planck Institute, representing several projects, say that the violence - in particular the harassment of tourists — raises questions about field researchers' safety and puts conservation efforts in jeopardy.

The attackers, who the researchers say represent only a small fraction of Galapagos fishermen, were demanding that a 50-tonne quota on lobster be increased. The fishing community had taken part in setting the quota, and had agreed to it, but some fishermen became agitated when it was reached just two months into a season that normally lasts four months.

To appease the fishermen, Ecuador raised the quota by 30 tonnes — alarming researchers and conservationists. Fishermen have resisted monitoring since the unrest, and it is not clear whether fishing will stop when the new limit is met.

The protesting fishermen also called on the government to open the Galapagos to shark fishing and long-line fishing for tuna. Conservationists believe that these would be disastrous for the islands' ecosystem.

"Obviously, if violence is rewarded in that way it tends to lead to more violence," says Alan Tye, who was acting director of the research station during the recent trouble. He says at least two of the faction's leaders are in custody, and there are warrants out for others.

But in the past, similar prosecutions have been unsuccessful. Tye says that he hopes that the area will have a stronger police presence. "If all goes well this time it may turn back this process of rewarding violence," he says.
Virtual laboratory will recreate classic biology experiments

Vera Bettenworth and Alison Abbott, Munich Science historians and computer scientists in Berlin are working to create a virtual nineteenth-century physiology laboratory on the Internet.

The project will allow people to learn how biologists first moved from observation to experiment. Its backers hope that it will give students and the public an insight into the history of science and a stronger understanding of the scientific method.

The virtual laboratory will recreate classic experiments - such as the twitching frog's leg that showed that electrical stimulation can make muscles contract - on the web.

"An experimental approach to life was very new in the nineteenth century," says Hans-Jörg Rheinberger, director of the Max Planck Institute for the History of Science in Berlin, who is coordinating the project.

Rheinberger's team is collecting and digitizing the scattered documents and drawings of early physiologists for the website, which will be launched next year.

Eventually the virtual laboratory will be interactive. "The site will be used not only by archivists and researchers in museums and scientific institutes, but also by the general public," says Sven Dierig, a member of Rheinberger's team. "Historic instruments help the public understand experiments much more easily than today's 'black boxes,'” he says.

Robert Bud, head of information and research at the Science Museum in London says that it "is a very ambitious and challenging project which links the public to the scientific community".

But the project needs to raise money for its software. So far, the project has a sponsor, the Volkswagen Foundation, only for its scientific component.

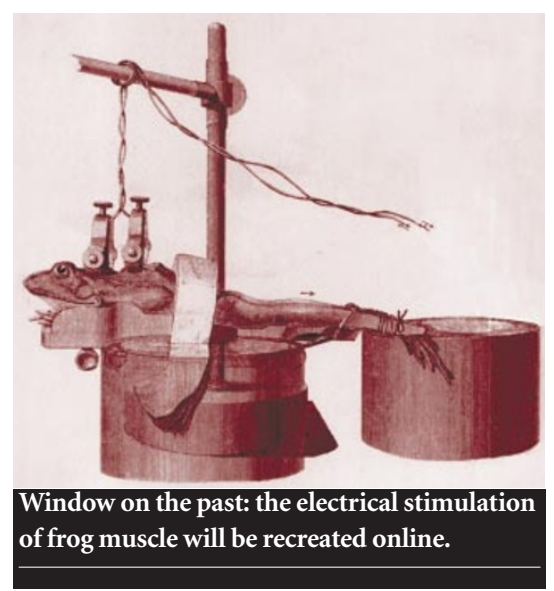

